DOI: $10.20472 / T E .2015 .3 .4 .007$

\title{
THE AUTONOMY OF HIGH SCHOOLS AND ITS IMPORTANCE FOR LIFELONG EDUCATION IN ALBANIA AFTER 90 YEARS: A COMPARATIVE ANALYSIS
}

\author{
MIRELA TASE, MANJOLA XHAFERRI
}

\begin{abstract}
:
Changes in the higher education system in Albania based on the requirements of the Bologna Process and European qualification for determining criteria of the workers. The Bologna process which began in 2003 with the signing of the Bologna declaration has led to the development of the European Higher Education Area combining respect for the diversity of programs, institutions and educational traditions in specific countries. As results of these process Albanian universities have introduced the following, training at three levels (licentiates, Master's and PhD). Through this paper we shall try to show what the tools are needed to achieve autonomy and put in the efficiency for our university system to serve a quality education and increase the academic quality of higher education institutions themselves
\end{abstract}

\section{Keywords:}

Keywords: autonomy, training, competitive, efficiency, propaganda

JEL Classification: A29

\section{Authors:}

MIRELA TASE, University of, Albania, Email: mirelatase@hotmail.com MANJOLA XHAFERRI, University ofl, Albania, Email: mxhaferri@yahoo.com

\section{Citation:}

MIRELA TASE, MANJOLA XHAFERRI (2015). The Autonomy of High Schools and its importance for lifelong education in Albania after 90 years: A comparative analysis. International journal of Teaching and Education, Vol. III(4), pp. 81-91., 10.20472/TE.2015.3.4.007 


\section{INTRODUCTION}

Autonomy although never explicitly stated, has been a central theme in the debate on the reform of universities over the centuries. It was perceived as a key element that will allow the transformation of the institution in ensuring freedom of research and teaching. Institutional autonomy of the university is a fundamental value. It should be noted that autonomy is a necessary but not a sufficient condition to ensure the autonomy of academic freedom in the broadest sense by (Stichweh, 1994) these means:

- The ability to take independent decisions within the limits of institutional commitment

- Establishment of a system of values and the determination of the forms of capital and structuring which will allow scientists to advance research in the relevant fields.

- Establishment of criteria such as access to institutions at the level of scientists and students

Autonomy, when exercised with a sense of responsibility and accountability will inevitably lead to perfection: a) in terms of academic, b) in government and c) financial ${ }^{1}$ management institutions. If it will not be expressed in the following three basic pillars, we can then safely conclude, that autonomy is misused.

$>$ The academics of autonomy is the freedom to decide on academic matters as curriculum, teaching materials and pedagogy, student assessment techniques, methods of transmitting knowledge etc. ${ }^{2}$

$>$ The administration of autonomy to the institution's freedom to manage its own affairs in connection with the administration. This is the freedom to manage affairs in such a way that it stimulates and encourage initiative and development of individuals working in institutions and in this way the institution itself.

$>$ The financies of autonomy is the freedom to use the institution for financial resources available to him . He must do it in a way to measure taking into account its priorities. Autonomy and accountability are two sides of the same coin

$>$ The Autonomy of staff, HEls are responsible for selecting and hiring staff, their academic staff promotion and salary setting.

\section{What are the reasons of institutional autonomy?}

These last two decades, we have heard more about the institutional autonomy of higher schools. The referring of this experience by different western countries have shown that the best operations have proved successful in other levels of management. There are several reasons why the issues of academic freedom and university autonomy have reappeared on the agenda in recent years.

${ }^{1} \mathrm{HEl}$ are high education institute 
1. The fall of dictatorships and authoritarian regimes in the former communist countries of the former Soviet Union and in Eastern European countries where our country is, are also included,here.

2. ${ }^{3}$ The development, and undoubtedly influence in the world is leading by the creation of large firms especially multinationals.

3. The development of faster and more technology thanks to new communication tools.

4. The distance of education consequently creating de fact or law universities in 'virtual' activities, and whose connections which extend into more countries and are almost universal. They escape from state control by remaining virtual.

\section{The value of autonomy of higher education for lifelong education (comparative perspective)}

The forms of education in European universities are different. The work of education can be centralized (within faculties) or decentralized (within departments or high school)

Today in Europe we operate and many centers of education do as a form of interaction between universities and businesses. The globalization and development of information technologies and the trend for a closer cooperation between European universities in the field of education has became priority need for giving autonomy to public institutions. In our country, this past decade has seen a collaboration of public and private universities with counterpart universities which enable the exchange of experiences in the areas where they are of interest. This has brought a qualitative increase in the context not only for improving the curriculum, but also in the training of academic staff which is reflected in the improvement of the quality of teaching and scientific research.

The EUCEN network (European network of university education) is a network which is created to promote methods in the field of education. In this network of 163 universities from 33 collaborating European countries being a member with full rights, but there are universities that are outside the framework of the European Union. Part of this network is the University of Vlore. (We hope that other universities also become part of the system as quickly).

The objectives of this network are to promote, development and support of the education of all policies of European universities, the establishment of high standards of quality teaching and provision of funds for a high level of education, encouraging the inclusion of best practices and innovations in the field education, creation of conditions for the exchange of experiences and information, as well as cooperation between the members and the most important European institutions. It should also be noted that this organization has influenced in European policy development in the field of education at the university level. One of the significant points of life through education is the

\footnotetext{
${ }^{2}$ Authoritarian regime fall in Albania after 1990
} 
involvement of American universities which would suggest that adolescents are addressed. Offers in the field of education for young people entered the American university in the late 19th century. Today they operate under the banner "Advanced "Universities" which represent a strong combination of structural standpoint in many colleges. Is another form of independent study program (individual studies). They work with adolescents to be better informed with higher education. There is another form of open universities (the organization of free themes). To us this method is an extension of the great campus finds especially in high non-public schools, which are trying to through organization of free themes to promote their achievements in institutions

This means that organizing free hours with certain themes giving young people the opportunity to come and to be part of these beautiful experiences in order to be able to evaluate and determine directions simultaneously and in the university they want to attend. In our country this practice has begun to apply in these last 5-6 years, especially in public universities not allowing young people to inform the branch that they will choose. This is seen as an innovation in our country which affects the process except for the youth media which plays a very big role in promoting the values that carry these schools and that will be a window for the information to you. Another form of training is the cyclical program which consists of a combination of theoretical knowledge in higher education with professional experience, for example in the implementation of technology at Massachusetts Institute. When we say professional experiences, we mean the application of this knowledge in practice.

For example, the University of Durres has in recent years taught the practice of students in the field of tourism management develops in this city that businesses thanks to a collaboration between the university and the operators themselves which brings private information of these new businesses with employees and their preparedness will work the way in this field.

Such has been the experience of the collaborative university in the field of tourism (Vlore and Shkoder ).

On the other hand the government program is working hard for the inclusion of a large number of young people in vocational schools in those branches which need more and more domestic market, as regional and international though not he. This is being realized in cooperation between state institutions and non-profit organizations themselves for involvement in several months and even more in-depth studies of the young men and women. But they will today find employment as a big problem not only in their country but wider.

From the above cases it is clear that the main purpose of higher education in Europe and the USA is a lifelong education. One of the reasons for a very quality education in higher education in our country is centralization, which is manifested by the fact that the Ministry

\footnotetext{
${ }^{4}$ Advanced Universities are find in development country
} 
of Education acts as an employer who possesses the right of ownership and control over it.

The ministry of education through educational reform that seeks to pass in parliament soon hopes to give financial autonomy to higher public schools and shall delegate those responsibilities that until now she was carrying. But for Albania as a small country and emerged after the collapse of 50-year-old communist system. There are conditions that the Ministry of Education as a higher educational institution in the countries law enforcement to give up the financing of higher education and scientific research especially the ? This attitude has led opposition to our ministry not only in the ranks of academic staff and students themselves. This is because they know that after that deleted pay increase of tuition fees for Albanian families has become unsustainable

This situation not seen in the USA where schools also financed by public funds. This is considered as a manifestation of socialist totalitarianism where our country was part of the system. As stated Andrezey Walicki: modernization of universities "from above" is an impossible thing for Oxford and Cambridge.

In 1990, Albania had just 14,000 students and a limited capacity. The selection of students and academic staff was on the basis of merit and of what was known as the "biography" of the person and the student. Thus, in the Albanian society, the mass, felt desire and requested the opportunity and the right to be absent or limited to higher education. This explains the 'pressure' of social extensive studies which are higher after the $90-\mathrm{s}$.

This has led to the expansion of the reception of capacities of state institutions of higher education, the opening of several new universities, the transformation of higher institutes at universities and providing opportunities facilitating layers persecuted policy that once had been deprived of this right, etc. But it was not accompanied in parallel with the increased funding to ensure quality, adequate infrastructure, and support of scientific research etc.

In the social and economic transition, higher education in Albania has suffered a tremendous mass appeal that has capacities and opportunities. This mass appeal, probably is important as educational policy, was not divided into stages, studying them. This factor led to a certain extent in the fall, sometimes dramatically, the quality, rather to bring its expected improvement

\section{The autonomy of educational institutions in our country (comparative analysis with other countries)}

Education in Albania is one of the main functions of universities to achieve their goal of working to provide benefits in this country. The traditional model of education in universities includes Stationary education in line with the directives of education to be coherent. In some cases they are supplemented by post-graduate studies. We must 
admit that our curricula are not fully completed by the subjects. The information vacuum level is not taken into the bachelor degree and completed the postgraduate level, which turns a financial cost to the students and for the labor market. The reason is that the structural organization in most of the universities in our country do not offer opportunities for research in the education in marketing. Studies such as EMI have become an important part of the modernization of the system of management education centers operating in European universities. However, the distributed structure of education in high schools (which are managed at faculty level) do not allow carrying out actions in structures. This situation is the result of measures too rigid and inflexibly applied in our educational system. The consequences of this differentiation can be seen clearly while we study and compare the development of education in Albania and foreign universities before and after 90.5

Figure 1: Shows us the number of HEls to a million people in 2014 - Albania and a group of European countries

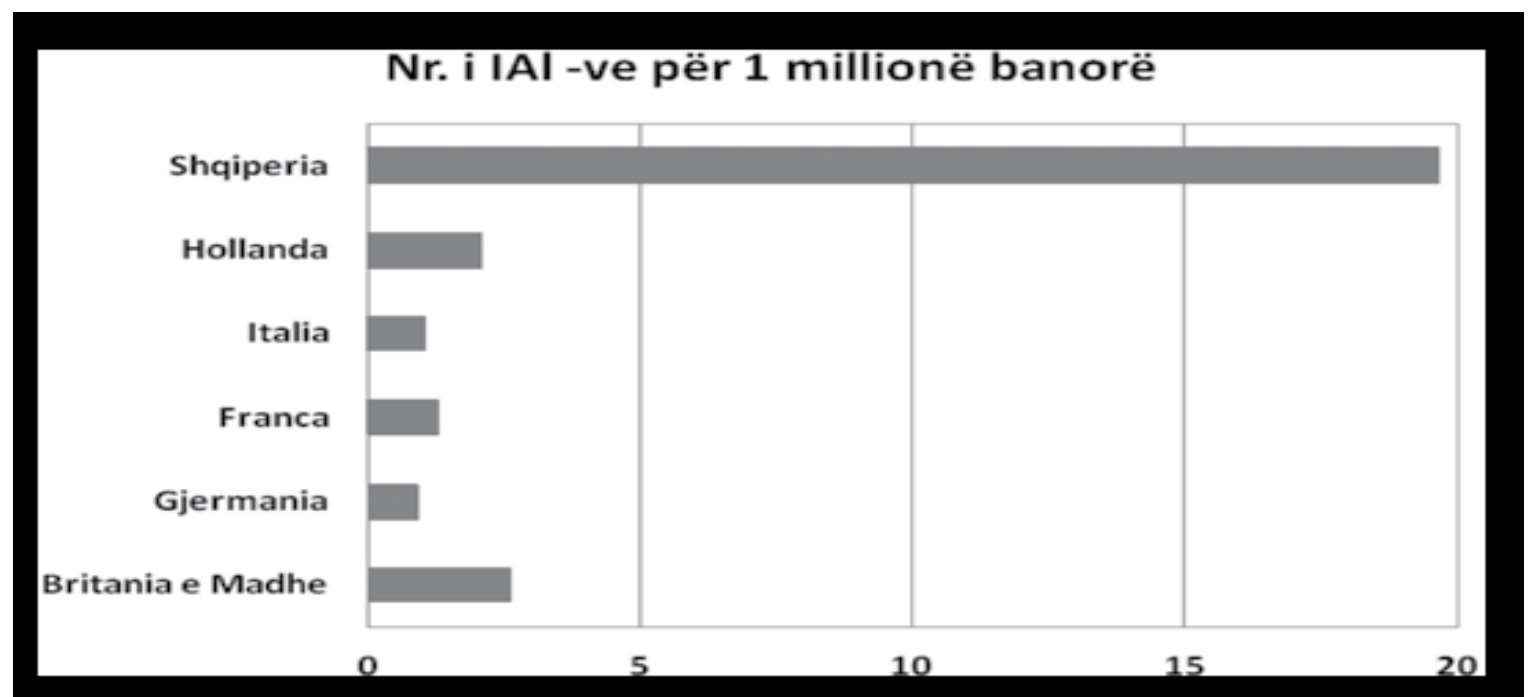

Source: Data for HEls are collected by the Bank UNESCO World, while the population from UN" Population Prospects."

${ }^{5}$ After 1990 many private university are open in Albania 
In Albania there are about $20 \mathrm{HEl}$ for a million, almost eight times more than countries like the UK, which has internationalized higher education and has a large percentage of foreign students.

On the other hand was a rapid increase in participation in various forms of education and on the other had few developments in the field of education which depended by central policies. Following the treatment of our subject we will consider the University of Glamorgan in 2006. Here was a small college in Wells (about 2000 students who trained in accordance with the old forms of education) which attracted more than 20,000 students in various trainings over 8 years. Non-traditional training method was implemented and synchronized with the old methods. Funds for the development of the content of curricula that were badly needed for distance education and for the organization and involvement in the learning process were provided by the European Community. The ability to increase the quality of areas in education for a large number of people carried out a fairly efficient strategy that is based on a sound market knowledge and education. The gap caused by the absence of a systematic study of the Albanian educational market can be filled in part by the results of research conducted within projects funded by the European Social Fund.

Search in this area is being conducted to determine the number of individuals who are interested in training as a need of the stakeholders in the education process, as well as the structure of the group of experts in this field that are cognitive of it.

Thus the educational market we have been focusing more on include schools which were seen as an opportunity for the adoption of lifelong education programs. The parameters were expressed in the form of a list of required staff, equipment and investments .Unfortunately, the universities from the organizational standpoint are usually not ready for this kind of activity. The structure of public schools in our country do not allow monitoring of the economic situation and in particular the labor market. We are studying about autonomy from state institutions from the financial perspective, curricula , and mode of assessment of students. We have designed graphics with responses received from academic staff and then make an appropriate analysis of the situation. 


\section{Graphic 1: Academic staff not are free to build curricula}

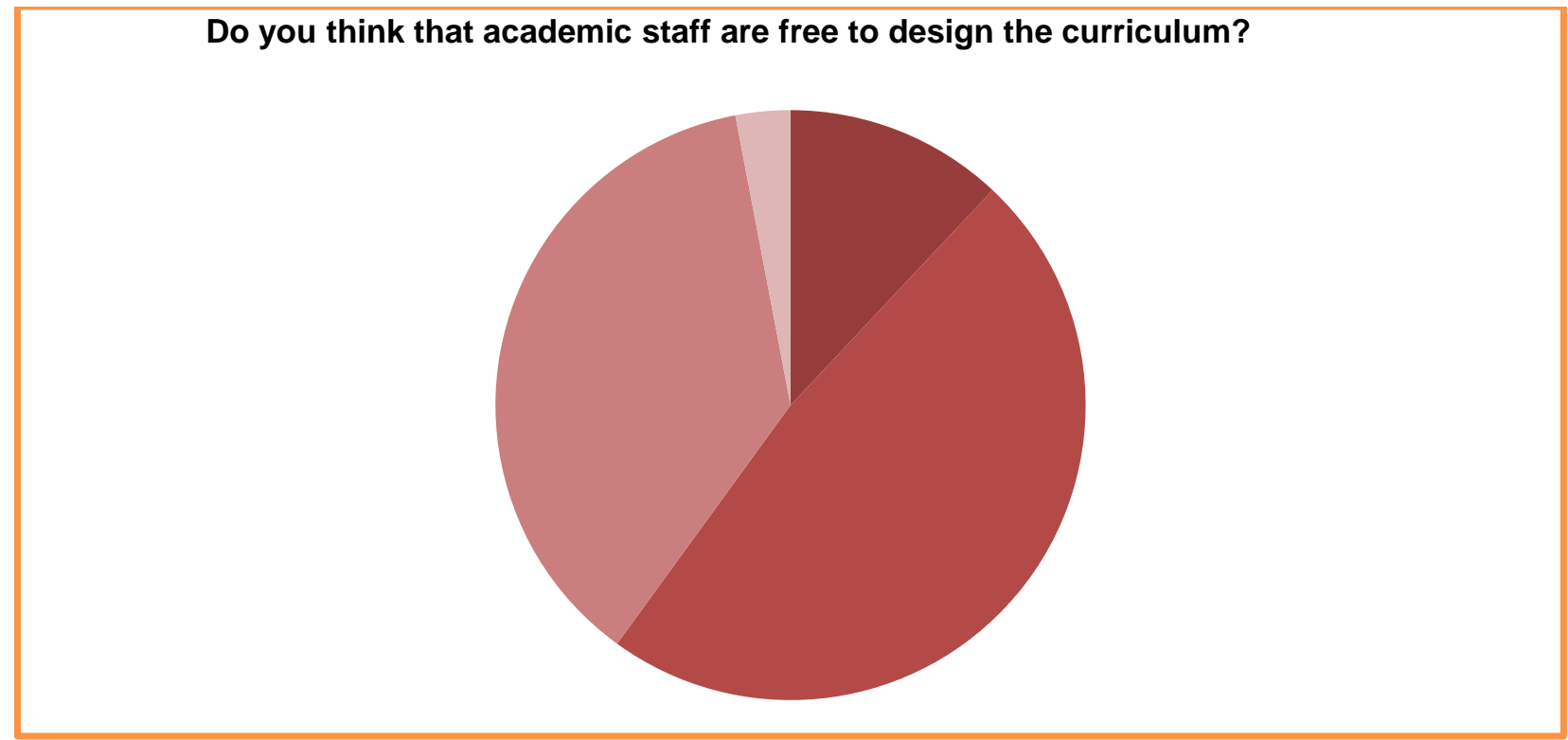

Source:The data are taken by "Aleksander Moises" University

Not at all $12 \%$

Less $48 \%$

Sufficient $37 \%$

$3 \%$ more

From the graphic no 1 shows us that the academic staff are not yet strongly free in the way they build curricula but they need to work more in public institutions and also in the private space to be more created in the curricula staff. Often these curricula copied from the outside and does not fit with our labor market. But the biggest problem in the design of such curricula is the mismatch of theoretical knowledge with the terrain that they face to put their knowledge into practice. This creates a great confusion of youth as well as a lack of sense of confidence for education in our schools 
Graphic 2: shows us the answers by percentages

Do you think that is independent academic staff in the use of valuation techniques to students

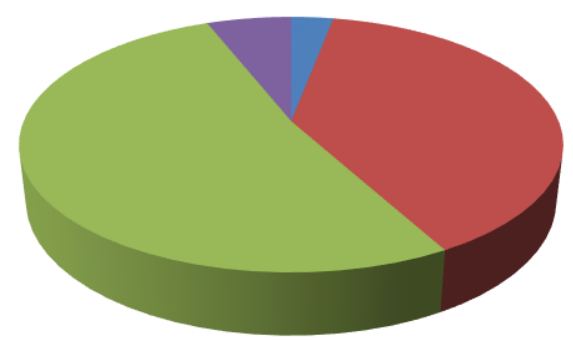

Source: The date from University of Durres

Not at all 3\%

Less $39 \%$

Sufficient $52 \%$

More 6\%

Even in this graph it is clear that despite the changes that have occurred in the education system these past 25 years, in terms of the way that academic staff assessment that students still felt conditioning in evaluation mode and it says in answer to give away university professors "Aleksander Moisiu"

\section{University budget and their structuring}

Albania invests in higher education several times less as much as its neighbors. This investment is even incommensurable, when comparisons are made with the most developed countries of Europe. State budget today provides about 38 million euro to support over 126,000 students in public HEls. This amount can be added to nearly 20 million other income from subsidiary, secured by the HEls, which brings the figure at around 460 euro per student in public sector

The results of the analysis of the total budget of many universities in our country show that about $70 \%$ of university income funds provided by state funds and the rest from secondary to university itself. Until 1990 the entire education system in our country has been funded by the government. At that time the state allocate a good part of the budget for education in all respects whether for academic qualification, for technical respects. But after 90 years as well as in the education sector we have been affected by the transition of power what was reflected across these 23 years. We have created a lot of problems that still have not received needed monies.

Our budget is very low in education, and for the field of research but also in the range of qualifications of teaching staff. From year to year the budget was made available for disposition of education has been growing, but not enough to cover all the needs in the system itself. 
The budget for education that after 92 years there has never been higher than $3 \%$ of GDP, being shaky in the interval 2.2-2.8\% / GDP. Western developed countries, in the framework of the OECD, their financial university education in levels 5-8\% of GDP, of which $1-3 \%$ of GDP goes directly to higher education and research.

At present, Albania spends on higher education $0.4-0.6 \% \%$ of the GDP, as well as many of HEl's common public and nonpublic.

At present, Albania has about 161,500 students, a number that (if not reformed by the system) will tends to increase (in the next 5 years this number could go up to 175 to 180,000 students), and in 1350 developed study programs country HEI 59 (44 non although some of them are formal - and 15 public). This growth goes in the opposite direction by increasing investment or standards in teaching and research.

According to the data of last 10 years shows that there has been an increase in funding for education from 6 billion in 2006 to 9.2 billion in 2009. But I see how education takes a percent of GDP from 1991 until 2012.

\section{Graphic 4 : shown us that the budget for education as the percentage of GDP}

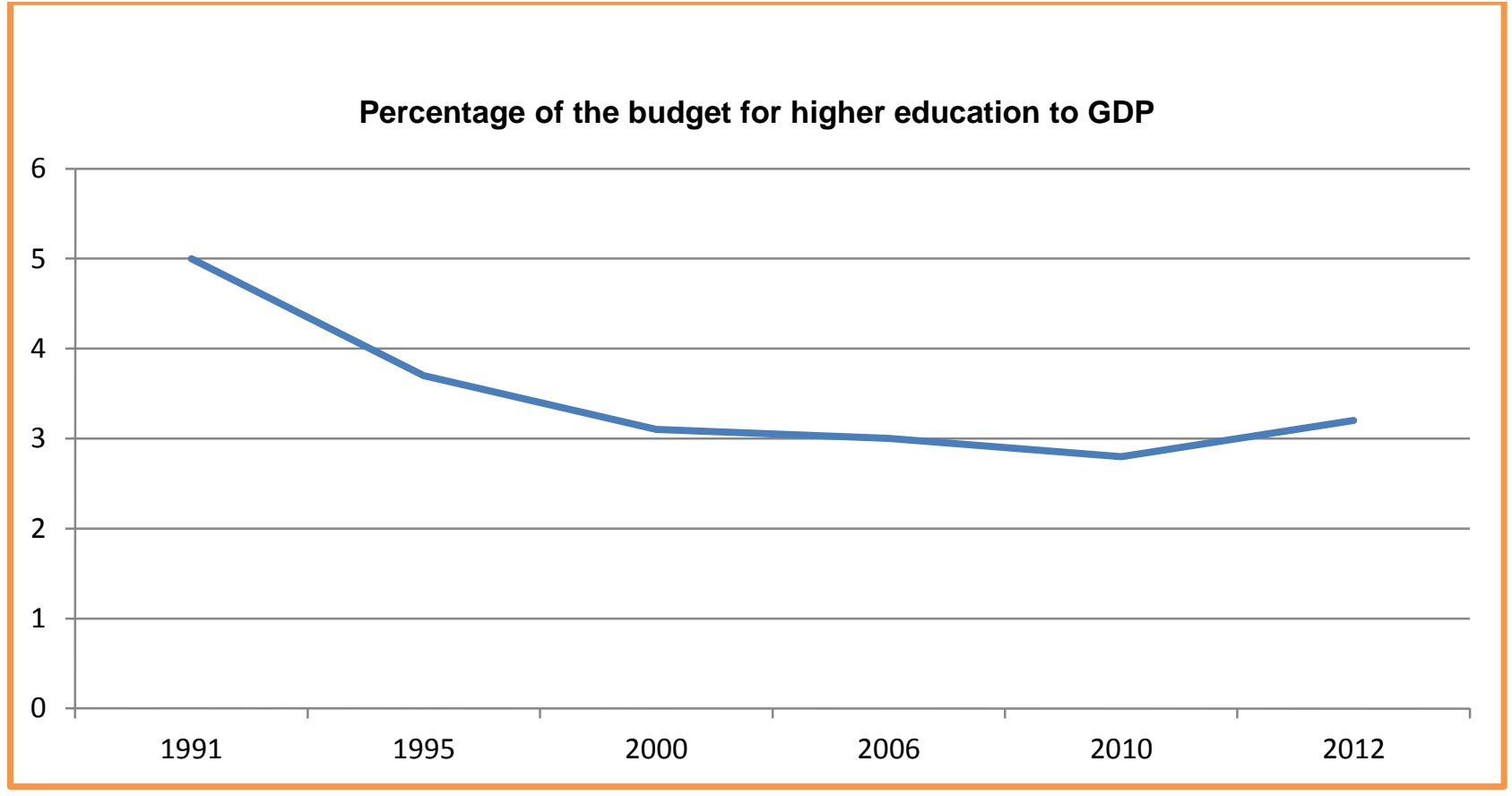

Source: The data from Ministry of Education

is smaller compared with the OECD countries. As compared with regional countries Albania is always about $2 \%$ less. However, as regards the management and governance of universities it is planned for the government to be the main sourse of financial management and thus realizing the continued control of their own to be constantly informed about the new funding scheme. The government manages the funds for education. 
In this regard, the committee of educational reform in Albania suggests the forms of financing in the future to diversify, but it is necessary to increase significantly and progressively the financial support from the state. These forms include:

1. Direct funding from the state budget (in grants).

2. Income from economic activity profitable. Public HEls should create income from their academic products and infrastructure; scientific work; patents; publications;

3. The different donations. This form has so far not recognized in public sector and, as such, should be regulated by law for the future.

4. The contribution of business and local authorities.

5. The student fees.

\section{Conclusions and recommendations}

As noted above from our educational system requires a deep reform if the structural standpoint (curricula and their adaptability to market needs, the funds to be allocated connected with the research, the training of academic staff)

To have a long-term development in Albanian recommended university system

1. Autonomy: a) full academic b) Financial c) administrative and d) personnel

2. A constitutional different status which guarantees autonomy

3. A clear institutional organization of independent and effective, where the division between academic and financial side is clear.

4. A possibility for financial discriminatory treatment based on the same principles

5. Ensuring the quality and standard of teaching and research, competitive with those of developed European countries

\section{References}

Association of Indian Universities: "Excellence in Achieving Social Relevance in Higher Education". $1993, \mathrm{p}$ 20-35

Arbana , Bexhet "Education at a crossroads", Tirana 2003 , p 20-23

Institute of Pedagogical Studies "Education in Albania", Tirana 2003

John Dewey "School and society " Tirana 2003

Sina ,Fisnik "Education in transition", Tirana 2003

John Taylor Gatto ,Hamza Yusuf Hansan, Dorothy Sayers, "Educate your children in modern times" Tirana 2008 p 9-11

Autonomia programowa uczelni Warszawa 2011, p 10-11

http:// www.elearnıngeuropa.ınfo/pl/users/eucen 27.03.2012 